\title{
Rancang Bangun Sistem Pembacaan Jumlah Konsumsi Air Pelanggan PDAM Berbasis Mikrokontroler ATMEGA328 Dilengkapi SMS
}

\author{
I Made Nova Suardiana ${ }^{1}$, I Gusti Agung Putu Raka Agung ${ }^{2}$, Pratolo Rahardjo ${ }^{3}$
}

\begin{abstract}
PDAM is still using analog flow meter. For PDAM customers, the information on analog flow meter are difficult to access and converted into payment amount. The system with analog read, PDAM officer was recorded by manual methods of data customer on the amount of water consumption. In this research using a water flow sensor YF-S201. Microcontroller ATmega328 receives the output pulses from the sensor. LCD is display information usage amount, time and date in real time. The module IComSat v1.1-SIM900 GSM / GPRS Shield SMS sending SMS based commands received from the customer and PDAM officer. The results achieved in this research is a sensor YF-S201 is able to read the amount of water consumed PDAM customers with an average deviation of $0.39 \%$. The tests showed the result of conversion of payment are in accordance with the PDAM payment model in Gianyar district.
\end{abstract}

Intisari-PDAM hingga saat ini masih menggunakan flow meter analog. Bagi pelanggan PDAM, Informasi pada flow meter analog sulit diakses dan dikonversi menjadi jumlah pembayaran. Dengan sistem pembacaan analog, petugas PDAM masih mencatat dengan metode manual data jumlah konsumsi air pelanggan. Pada penelitian ini menggunakan flow water sensor YF-S201. Mikrokontroler ATmega328 menerima output pulsa dari sensor. LCD menampilkan informasi jumlah pemakaian, waktu dan tanggal secara real time. Modul IComSat v1.1SIM900 GSM/GPRS Shield SMS mengirim SMS berdasarkan perintah yang diterima dari pelanggan dan petugas PDAM. Hasil yang dicapai dalam penelitian ini adalah sensor YF-S201 mampu membaca jumlah konsumsi air pelanggan PDAM dengan rata-rata penyimpangan sebesar 0,39 \%. Pengujian menunjukkan hasil konversi pembayaran sudah sesuai dengan model pembayaran PDAM di Kabupaten Gianyar.

Kata kunci : PDAM ATmega328, Sensor YF-S201, SMS

${ }^{1}$ Mahasiswa, Teknik Elektro dan Komputer Fakultas Teknik Universitas Udayana, Br. Seseh Singapadu Sukawati 80582. Indonesia(telp:087860502955; e-mail: nova.spd6@gmail.com)

${ }^{2}$ Dosen, Jurusan Teknik Elektro dan Komputer Fakultas Teknik Universitas Udayana, Br. Anggarkasih, Medahan, Blahbatuh, Gianyar 80581 INDONESIA (telp: 081999898301; e-mail: igapraka@yahoo.co.id)

${ }^{3}$ Dosen, Jurusan Teknik Elektro dan Komputer Fakultas Teknik Universitas Udayana, Jln. Tukad Yeh Panan Blok 19 No. 32, Dsn./Br. Jadi Anyar, Ds. Banjar Anyar, Kediri, Tabanan 82123 INDONESIA (telp: 085738213637; e-mail: pratolo@unud.ac.id)

\section{PENDAHULUAN}

PDAM masih mengumpulkan data penggunaan air pelanggannya dengan memantau secara langsung meter air pada pipa pelanggan di setiap rumah setiap bulannya.PDAM hingga saat ini masih menggunakan flow meter analog[1]. Bagi pelanggan PDAM, informasi pada flow meter analog sulit diakses dan dikonversi menjadi jumlah pembayaran.Kesalahan pencatatan data konsumsi pelanggan PDAM dapat terjadi karena rumah pelanggan sewaktu-waktu bisa dalam keadaan terkunci atau tidak ada penghuni, sehingga pada akhirnya petugas melakukan pencatatan dengan metode tafsiran dengan membandingkan data pada bulan sebelumnya.

Pada penelitian sebelumnya telah dibuatrancang bangun sistem jaringan nirkabel untuk pemantauan konsumsi air pelanggan PDAM menggunakan jaringan internet[1]. Pada penelitian ini tidak dilengkapi dengan total pemakaian dalam satuan pembayaran yang dapat diakses oleh pelanggan PDAM.Berdasarkan hal tersebut, maka ada keinginan untuk membuat sistem pembacaan yang dapat memberikan pelayanan yang lebih transparan kepada pelanggan PDAM dan memudahkan proses pencatatan data oleh petugas PDAM. Solusinya adalahdengan mengubah sistem pengukuran konsumsi air dari sistem analog menjadi digital dengan tampilan total pemakaian dalam satuan pembayaranserta media pengiriman data melalui SMS. SMS dipilih karena membutuhkan biaya yang lebih rendah jika dibandingkan dengan pengiriman data melalui media internet. Dalam penelitian ini dilakukan suatu perancangan sistem pembacaan jumlah konsumsi air pelanggan PDAM menggunakan sensor YF-S201 berbasis mikrokontroler ATmega328 dilengkapi SMS.

\section{Desain Sistem}

Pada desain sistem dijelaskan sensor dan rangkaianrangkaian yang digunakan dalam perancangan sistem pembacaan jumlah konsumsi air pelanggan PDAM berbasis mikrokontroler ATmega328 dilengkapi SMS.

\section{A. Water Flow Sensor YF-S201}

Water flow sensor YF-S201 digunakan dalam pengendalian aliran air pada sistem distribusi air, sistem pendinginan berbasis air, dan aplikasi lainnya yang p-ISSN:1693 - 2951; e-ISSN: 2503-2372

I Made Nova Suardiana : Rancang Bangun Sistem Pembacaan...

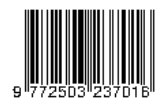


membutuhkan pengecekan terhadap debit air yang dialirkan. Water flow sensor YF-S201 dapat digunakan untuk mendeteksi aliran air hingga 30 liter/menit (1.800 liter/jam) [2]. Bentuk fisik dari water flow sensorYF-S201 ditunjukkan pada Gambar 1.

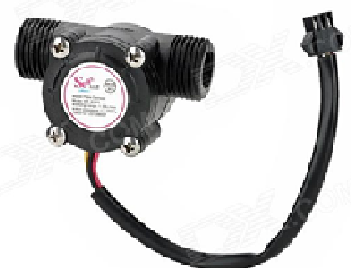

Gambar 1: Bentuk fisik waterflow sensor YF-S201

Water flow sensor YF-S201 memiliki diameter input aliran air $1 / 2$ inch atau sama dengan $1,25 \mathrm{~cm}$, memiliki panjang $5,6 \mathrm{~cm}$. Terdapat 3 kabel penghubung untuk mengoperasikan sensor ini yaitu:

1. Kabel berwarna merah : hubungan ke Vcc

2. Kabel berwarna kuning : hubungan ke Data

3. Kabel berwarna hitam : hubungan ke Ground

Untuk mendapatkan nilai aliran dalam satuan L/detik (Q) didapat dengan persamaan:

$$
(\mathrm{Q})=\frac{\text { Pulse Frequency } / 60}{7.5}
$$

Persamaan (1) merupakan persamaan untuk mendapatkan nilai aliran air dalam satuan L/detik. Q merupakan nilai aliran air dalam satuan L/detik. Angka 7.5 adalah konstanta untuk water flow sensorYF-S201 dalam keadaan horizontal. Angka 60 adalah faktor pengali waktu untuk satuan L/detik.

\section{B. Konversi Pin ATmega328 ke Arduino UNO}

Mikrokontroler yang dipakai pada penelitian ini adalah ATmega328. Mikrokontroler ATmega328 yang dikonversi menjadi sebuah modul Arduino UNO melalui proses burn bootloader. Burn bootloader adalah proses pengisian suatu program operasi atau yang disebut dengan bootloader pada sebuah mikrokontroler, sehingga dapat difungsikan seperti modul Arduino [3]. Arduino UNO menggunakan jenis mikrokontroler ATmega328, tetapi data pin pada Arduino UNO berbeda dengan ATmega328. Konversi pin dari mikrokontroler ATmega328 ke Arduino UNO ditunjukkan pada Gambar 2.

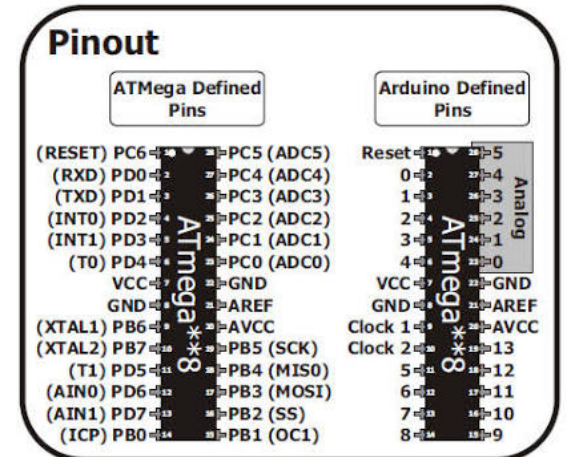

Gambar 2: Konversi pin ATmega328 ke Arduino UNO

Proses burn bootloader bertujuan untuk menyesuaikan maping pin pada Mikrokontroler ATmega328 dengan software yang dipakai yaitu software Arduino 1.0.5-r2.

\section{Modul IComSat v1.1-SIM900 GSM/GPRS Shield}

IComSat v1.1-SIM900 GSM/GPRS Shield adalah modul GSM yang diproduksi oleh perusahaan Iteadstudio. IComSat dapat digunakan untuk mengirim dan menerima data dengan menggunakan SMS (Short Message Service)[4]. Icomsat dapat dikontrol dengan menggunakan komunikasi serial AT commands.Modul GSM ini berfungsi menggantikan sebuah telepon seluler dalam hal pengiriman atau penerimaan pesan SMS. Namun demikian, sebuah modul GSM tidak bisa berjalan tanpa dikontrol oleh sebuah program. Dengan serangkaian perintah yang dibuat menggunakan bahasa pemrograman, instruksi-instruksi khusus dikirimkan dari komputer kepada alat ini melalui kabel yang dihubungkan ke terminal datanya [5]. Bentuk fisik IComSat v1.1 SIM900 GSM/GPRS Shield ditunjukkan pada Gambar 3.

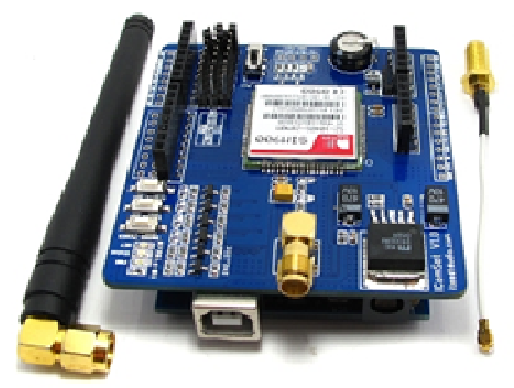

Gambar 3:IComSat v1.1 SIM900 GSM/GPRS Shield.

\section{Real Time Clock (RTC) DS1307}

RTC DS1307 adalah RTC serial dengan protokol komunikasi I2C (Inter-Integrated Circuit). Fungsinya adalah sebagai penyimpan data waktu digital yang dapat diakses oleh mikrokontroler. Selain itu, RTC ini juga memiliki RAM sebesar 56 byte [6].

Pada alat ini RTC DS1307 dijadikan sebagai komponen utama pada sistem penunjukan tanggal dan waktu. RTC (Real Time Clock) DS1307 bekerja dengan daya rendah (low power), memiliki kalender/jam BCD dan SRAM yang nonvolatile dengan kapasitas 56 bytes. Alamat dan data

ISSN 1693-2951 I Made Nova Suardiana : Rancang Bangun Sistem Pembacaan... 
dikirim melalui 2 kabel dua arah. Jam dan kalender pada DS1307 menyediakan informasi dalam satuan detik, menit, jam, hari, tanggal, bulan dan tahun. Banyak hari dalam satu bulan diatur secara otomatis oleh IC ini baik untuk 31 hari maupun kurang. Jam bekerja dalam format 24 jam atau 12 jam dengan indikator AM/PM. DS1307 dapat mendeteksi secara otomatis catu dayanya, jika catu daya ke sistem mati, maka secara otomatis DS1307 akan mengambil catu daya dari baterai (jika dipasang). DS 1307 memiliki 8 buah pin dan tersedia dalam bentuk 8-pin DIP serta 8- pin SOIC [7]. Konfigurasi dari DS1307 ditunjukkan pada Gambar 4.

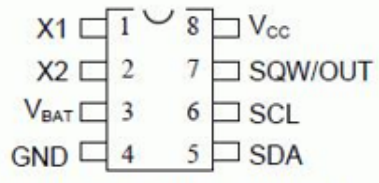

DS1307 8-Pin DIP (300-mil)

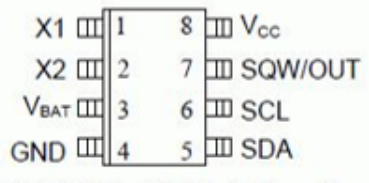

DS1307 8-Pin SOIC (150-mil)
Gambar 4: Diagram pin RTC DS1307

\section{E. Perhitungan Pembayaran Air di PDAM Kabupaten Gianyar}

Implementasi alat untuk sistem pembacaan jumlah konsumsi air PDAM menggacu pada pelanggan PDAM di Kabupaten Gianyar dengan golongan Non Niaga (NA) untuk Rumah Tangga (NA.1). Pada golongan Rumah Tangga (NA.1) digunakan istalasi pipa ukuran diameter $1 / 2$ inch dengan beban biaya administrasi setiap bulan sebesar Rp.10.000. Tarif air PDAM untuk golongan Non Niaga (NA) untuk Rumah Tangga (NA.1) ditunjukkan pada Tabel 1 [8].

TABELI

TARIF AIR PDAM GOLONGAN RUMAH TANGGA (NA1)

\begin{tabular}{|l|l|l|}
\hline No. & \multicolumn{1}{|c|}{ Pemakaian $\left(\mathrm{m}^{3}\right)$} & \multicolumn{1}{c|}{ Harga } \\
\hline 1. & $0-10$ & Rp. 17.000 \\
\hline 2. & $11-20$ & Rp. $4.250 / \mathrm{m}^{3}$ \\
\hline 3. & $20-30$ & Rp. $5.100 / \mathrm{m}^{3}$ \\
\hline 4. & $>30$ & Rp. $5.950 / \mathrm{m}^{3}$ \\
\hline
\end{tabular}

Berikut ini adalah contoh perhitungan pembayaran rekening air (NA1) $1 / 2$ inch

Pemakaian 0-10 $\mathrm{m}^{3}$

10 x Rp. 1.700

$=$ Rp. 17.000

Biaya Administrasi

Total

$$
=\text { Rp. } 10.000
$$$$
=\text { Rp. } 27.000
$$

2. Pemakaian $12 \mathrm{~m}^{3}$

10 x Rp. 1.700

$=$ Rp. 17.000

2 x Rp. 4.250

$=$ Rp. 8.500

$=$ Rp. 10.000

Biaya Administrasi

$=$ Rp. 35.500

3. Pemakaian $25 \mathrm{~m}^{3}$
10 x Rp. 1.700
$=$ Rp. 17.000
$10 \times$ Rp. 4.250
5 x Rp. 5.100
$=$ Rp. 42.500
$=$ Rp. 25.500

I Made Nova Suardiana :Rancang Bangun Sistem Pembacaan...
Biaya Administrasi

Total

$$
\begin{aligned}
& =\text { Rp. } 10.000 \\
& =\text { Rp. } 95.000
\end{aligned}
$$

4. Pemakaian $34 \mathrm{~m}^{3}$

10 x Rp. 1.700

$10 \times$ Rp. 4.250

10 x Rp. 5.100

4 x Rp. 5.950

Biaya Administrasi

Total

$$
\begin{array}{ll}
=\text { Rp. } & 17.000 \\
=\text { Rp. } & 42.500 \\
=\text { Rp. } & 51.000 \\
=\text { Rp. } & 23.800 \\
=\text { Rp. } & 10.000 \\
\hline & =\text { Rp. } 144.300
\end{array}
$$

\section{F. PerancanganPenelitian}

Penelitian alat ini dilakukan di Laboratorium Teknik Digital dan Mikroprosesor, Jurusan Teknik Elektro dan Komputer, Fakultas Teknik, Universitas Udayana, Bukit Jimbaran. Penelitian ini dimulai pada bulan Maret sampai Juni 2016. Adapun diagram alir penelitian dapat dilihat pada Gambar 5.

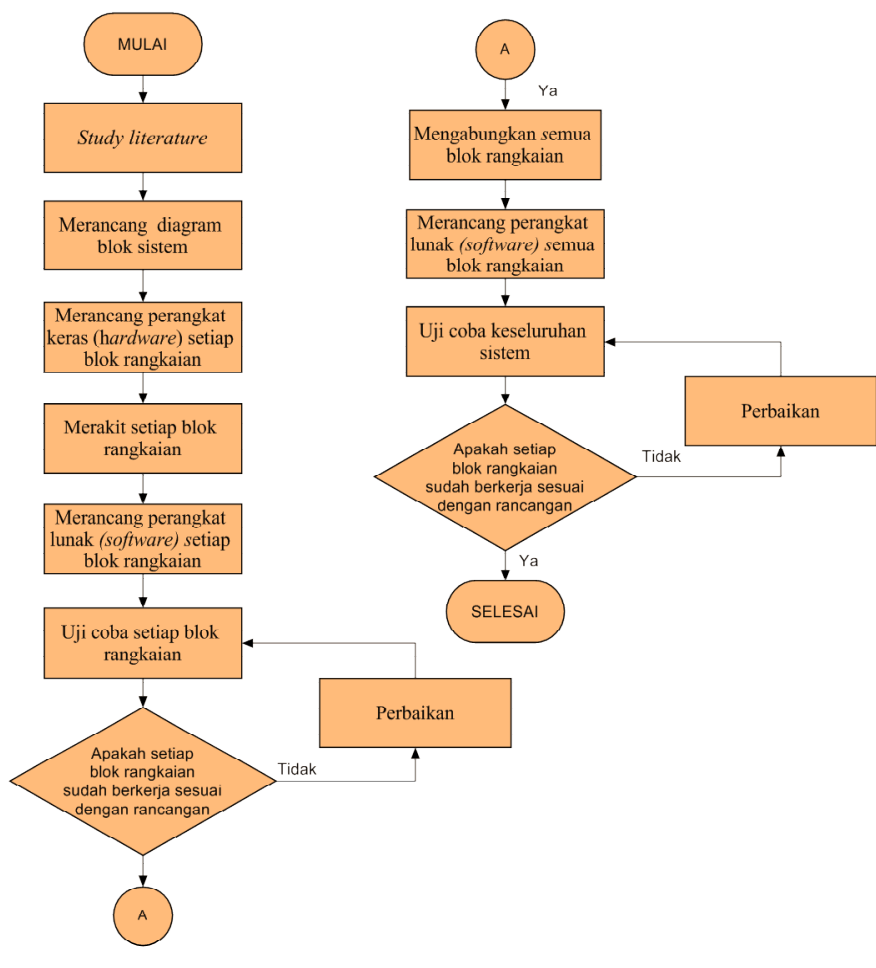

Gambar 5. Diagram alir penelitian

Diagram alir menggambarkan proses pembuatan sistem pembacaan jumlah konsumsi air pelanggan PDAM menggunakan sensor YF-S201 berbasis mikrokontroler ATmega328 dilengkapi SMS adalah sebagai berikut.

1. Dimulai dengan study literature sebagai acuan dalam pembuatan sistem.

2. Dari Study literature dilanjutkan dengan perancangan diagram blok sistem dan perancangan perangkat keras (hardware) setiap blok rangkaian.

3. Selanjutnya dilakukan perancangan perangkat lunak p-ISSN:1693 - 2951; e-ISSN: 2503-2372 
(software) setiap blok rangkaian dan uji coba pada masingmasing blok rangkaian.

4. Selanjutnya dilakukan pengabungan antara perangkat keras (hardware) dengan perangkat lunak (software).

5. Apabila seluruh sistem dapat bekerja dengan baik dilakukan analisa untuk mendapatkan hasil, selesai.

\section{G. Perancangna Perangkat Keras}

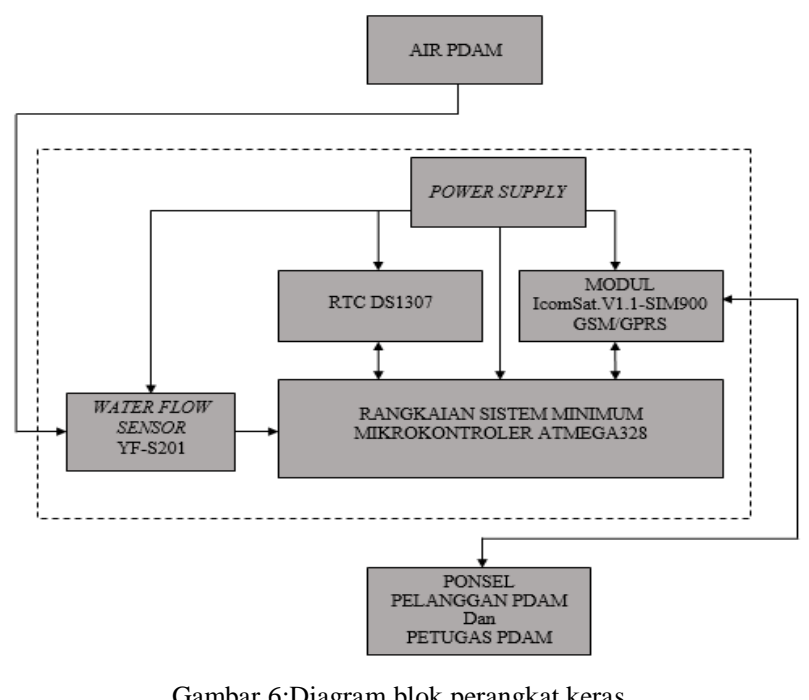

Perancangan perangkat keras yang dilakukan dalam pembuatan rancang bangun sistem pembacaan jumlah konsumsi air pelanggan PDAM berbasis mikrokontroler ATmega328 dilengkapi SMS adalah sebagai berikut:

1. Perancangan rangkaian sistem minimum mikrokontroler ATmega328

2. Perancangan rangkaian voltage regulator

3. Perancangan rangkaian LCD

4. Perancangan rangkaian water flow sensor

5. Perancangan rangkaian Real Time Clock

6. Perancangan rangkaian IComsat v1.1 -SIM900 GSM/GPRS Shield.

7. Perancangan rangkaian switch

8. Perancangan rangkaian USB ASP downloader.

9. Perancangan sistem secara keseluruhan

\section{H. Perancangan Perangkat Lunak}

Perancangan perangkat lunak (software) pada pembuatan sistem pembacaan jumlah konsumsi air pelanggan PDAM berbasis mikrokontroler ATmega328 dilengkapi SMS menggunakan software Arduino 1.0.5-r2 dengan bahasa pemrograman C. Pada penelitian ini digunakan flow water sensor YF-S201. Output pulsa dari sensor ini diteruskan ke mikrokontroler ATmega328. Informasi jumlah pemakaian, waktu dan tanggal secara real time ditampilkan pada LCD. SMS dikirim kepada pelanggan dan petugas PDAM berdasarkan informasi waktu yang telah ditetapkan pada rangkaian RTC dan perintah yang diterima oleh Modul IComSat v1.1-SIM900 GSM/GPRS. Pada digram alir tidak terdapat label "selesai", dikarenakan sistem selalu bekerja baik itu pembacaan sensor, proses konversi, penyediaan informasi waktu maupun menerima dan mengirim SMS. Sistem hanya akan di reset pada tanggal 20 jam 10:01 di setiap bulannya untuk mengulang siklus pembacaan jumlah konsumsi air pelanggan PDAM [8]. Adapun diagram alir perancangan perangkat lunak dapat dilihat pada Gambar 7. 


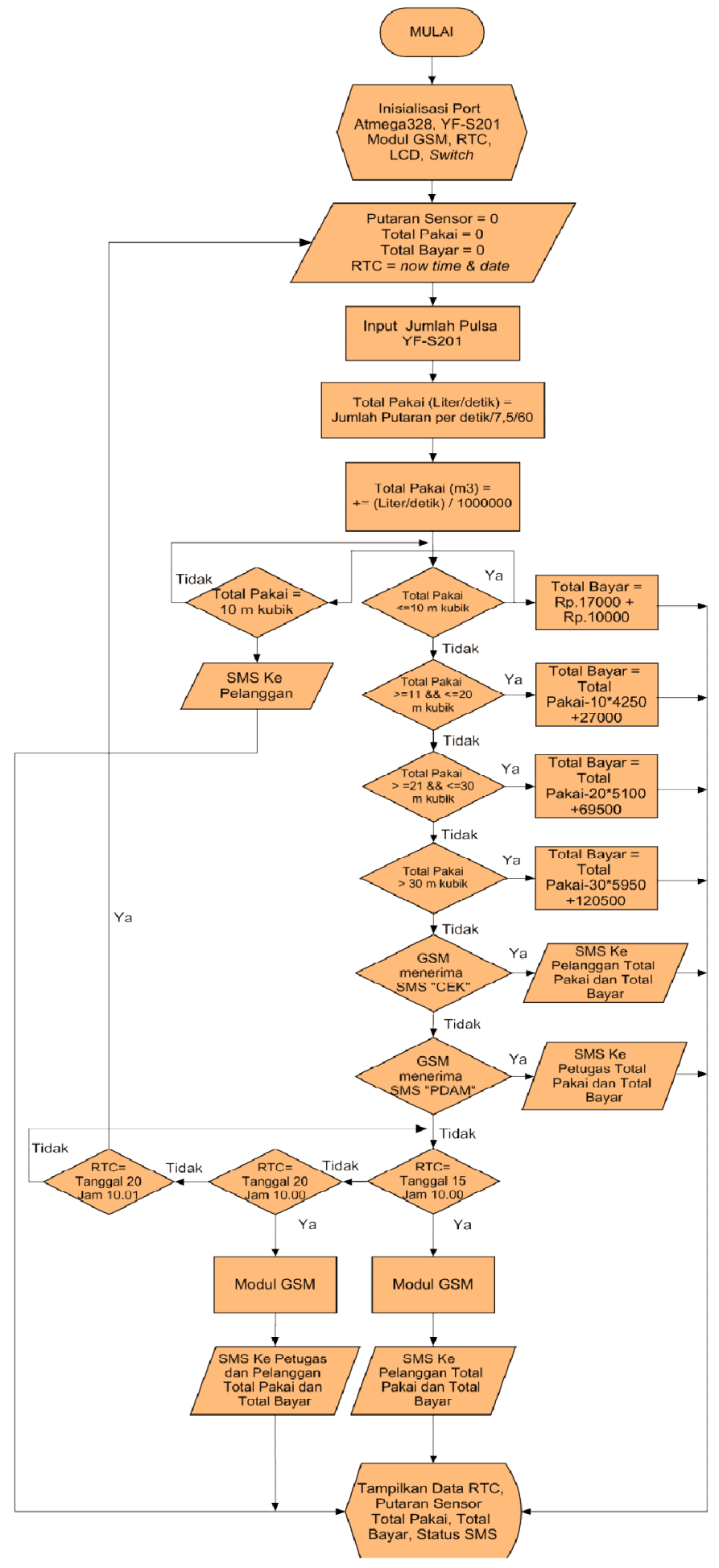

Gambar 7: Diagram alirperangkat lunak

\section{HASIL DAN PEMBAHASAN}

Hasil dan pembahasan rancang bangun sistem pembacaan jumlah konsumsi air pelanggan PDAM berbasis mikrokontroler ATmega328 dilengkapi SMS adalah sebagai I Made Nova Suardiana :Rancang Bangun Sistem Pembacaan... berikut.

\section{A. Realisasi Hasil Perancangan}

Realisasi rancang bangun sistem pembacaan jumlah konsumsi air pelanggan PDAM berbasis mikrokontroler ATmega328 dilengkapi SMS, ditunjukkan pada Gambar 8

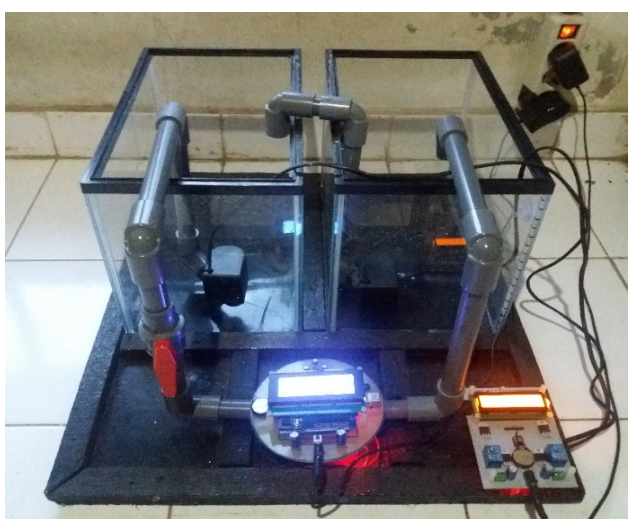

Gambar 8: Realisasi hasil perancangan

B. Pengujian dan Pembahasan Rangkaian Sistem Minimum Mikrokontroler ATmega328 dan Rangkaian LCD

Pengujian dan pembahasan rangkaian sistem minimum mikrokontroler ATmega328 dan rangkaian LCD bertujuan untuk mengetahui sistem minimum mikrokontroler ATmega328 bekerja dengan baik. Diagram blok dari pengujian pengiriman data program ke dalam Chip mikrokontroler ATmega328 ditunjukkan pada Gambar 9.

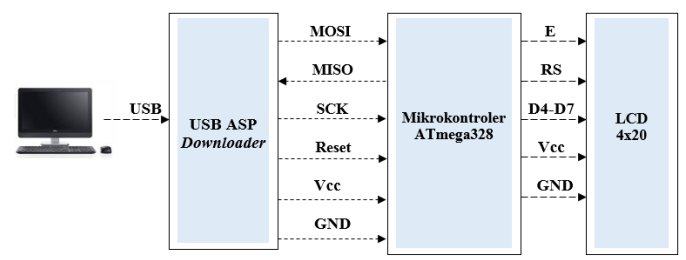

Gambar 9: Diagram blokpengujian pengiriman data mikrokontroler ATmega328 dan rangkaian LCD

Dari Gambar 4.2 dapat dijelaskan bahwa proses pengujian mikrokontroler ATmega328 ini menggunakan USB ASP downloader untuk mengirim data ke dalam Chip mikrokontroler ATmega328 melalui pin MOSI, MISO, SCK, reset, $\mathrm{V}_{\mathrm{CC}}$ dan GND, sedangkan dari komputer ke downloader menggunakan kabel USB. Hasil pengujian rangkaian sistem minimum mikrokontroler ATmega328 ditunjukkan pada Gambar 10.

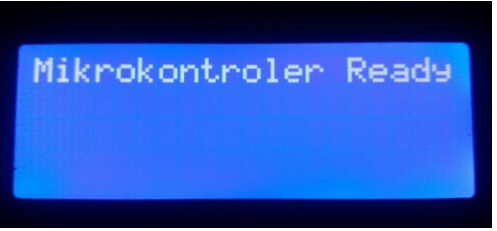

Gambar 10:Hasil pengujian rangkaian sistem minimum mikrokontroler ATmega328

p-ISSN:1693 - 2951; e-ISSN: 2503-2372 


\section{Pengujian Dan Pembahasan Pembacaan Nilai Water} Flow Sensor YF-S201

Pengujian dan pembahasan rangkaian water flow sensor YF-S201 bertujuan untuk mengetahui akurasi pembacaan sensor terhadap aliran air yang diberikan. Pada proses pengujian dilakukan kalibrasi nilai pembacaan sensor terhadap aliran air sehingga pembacaan nilai water flow sensor YFS201 menjadi akurat. Diagram blok dari pengujian pembacaan nilai water flow sensor YF-S201 ditunjukkan pada Gambar 11.

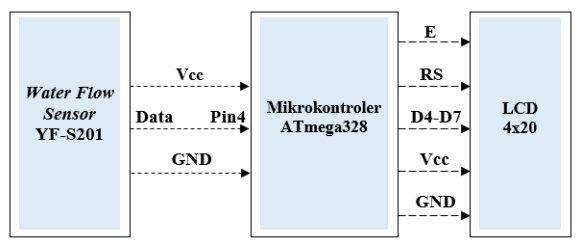

Gambar 11: Diagram blokpengujian pembacaan nilai water flow sensor YFS201

Hasil pengujian pembacaan nilai water flow sensor YF-S201 menggunakan mikrokontroler ATmega328 dengan tampilan LCD ditunjukkan pada Gambar 12.

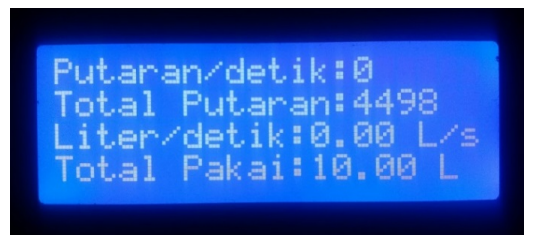

Gambar 12: Hasil pengujian pembacaan nilai water flow sensor YF-S201

Pengujian pembacaan nilai water flow sensor YF-S201 dilakukan dengan melewatkan aliran air yang memiliki debit air sebesar 0,075 Liter/detik atau dengan jumlah volume air sebesar 10 Liter. Tabel hasil pengujian pembacaan nilai water flow sensor YF-S201 ditunjukkan pada Tabel 2.

TABEL II

HASIL PENGUJIAN PEMBACAAN NILAI WATER FLOWSENSOR YF-201

\begin{tabular}{|c|c|c|c|c|c|}
\hline No & $\begin{array}{c}\text { Jumlah } \\
\text { Putaran } \\
\text { Pada } \\
\text { Sensor }\end{array}$ & $\begin{array}{c}\text { Jumlah } \\
\text { Putaran } \\
\text { Per 1 } \\
\text { Liter }\end{array}$ & $\begin{array}{c}\text { Hasil } \\
\text { Konversi } \\
\text { Sensor } \\
(\text { Liter })\end{array}$ & $\begin{array}{c}\text { Volume } \\
\text { Air Pada } \\
\text { Bak } \\
(\text { Liter })\end{array}$ & $\begin{array}{c}\text { Penyimpangan } \\
\text { Pembacaan } \\
\text { Sensor } \\
(\%)\end{array}$ \\
\hline 1 & 4498 & 449,8 & 10,00 & 10 & 0,0 \\
\hline 2 & 4492 & 449,2 & 9,98 & 10 & 0,2 \\
\hline 3 & 4541 & 454,1 & 10,09 & 10 & 0,9 \\
\hline 4 & 4480 & 448,0 & 9,96 & 10 & 0,4 \\
\hline 5 & 4463 & 446,3 & 9,92 & 10 & 0,8 \\
\hline 6 & 4519 & 451,9 & 10,04 & 10 & 0,4 \\
\hline 7 & 4507 & 450,7 & 10,02 & 10 & 0,2 \\
\hline 8 & 4497 & 449,7 & 9,99 & 10 & 0,1 \\
\hline 9 & 4488 & 448,8 & 9,97 & 10 & 0,3 \\
\hline 10 & 4475 & 447,5 & 9,94 & 10 & 0,6 \\
\hline
\end{tabular}

Berdasarkan hasil pengujian pembacaan nilai water flow sensor YF-S201 menggunakan mikrokontroler ATmega328 diperoleh hasil kalibrasi water flow sensor YF-S20 yaitu: 450 putaran yang dihasilkan sensor $=1$ Liter air yang dilewatkan sensor. Rata rata sensor memiliki penyimpangan pembacaan sebesar $0,39 \%$.

\section{Pengujian Dan Pembahasan Modul IComsat v1.1 - SIM900 GSM/GPRS.}

Pengujian modul IComSat V1.1-SIM900 Shield bertujuan untuk mengetahui modul bekerja dengan baik dalam melakukan penerimaan dan pengiriman perintah melalui SMS. Diagram blok dari pengujian modul IComSat V1.1-SIM900 ditunjukkan pada Gambar 13.

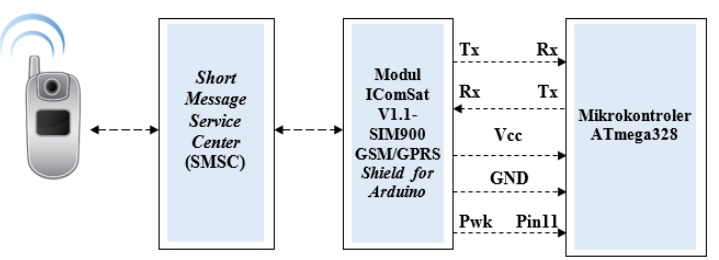

Gambar 13: Diagram blokpengujian modul IComSat V1.1-SIM900shield

Pengujian dilakukan dengan cara mengirimkan perintah melalui SMS dengan SMS yaitu "Test" ke modul IComSat V1.1-SIM900 Shielddengan nomor yang telah ditentukan. Jika SMS telah diterima maka modul IComSat V1.1-SIM900 Shield akan mengirimkan SMS balasan ke pengguna dengan isi SMS yaitu "Modul GSM Siap Digunakan". SMS yang dikirim modul IComSat V1.1-SIM900 Shieldditunjukkan pada Gambar 14.

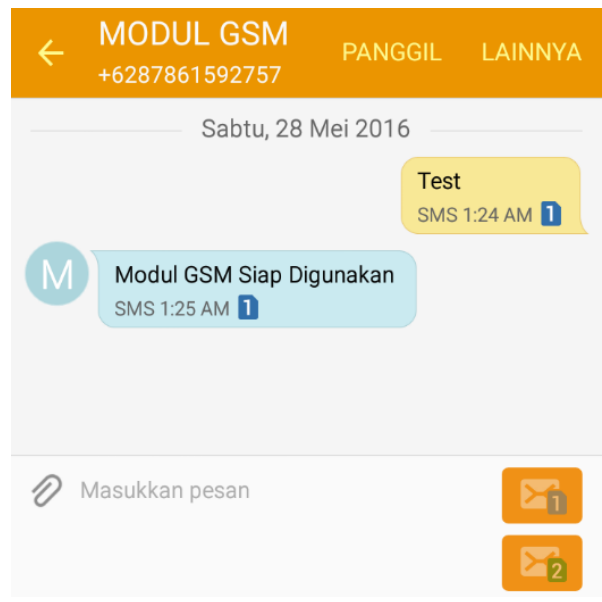

Gambar 14: SMS yang dikirim modul IComSat V1.1-SIM900 shield

\section{E. Pengujian Dan Pembahasan Rangkaian Real Time Clock}

Pengujian dan pembahasan rangkaian Real Time Clock bertujuan untuk mengetahui rangkaian yang dirancang dapat memberikan informasi tanggal dan waktu secara real time.Diagram blok dari pengujian rangkaian Real Time Clock ditunjukkan pada Gambar 15. 


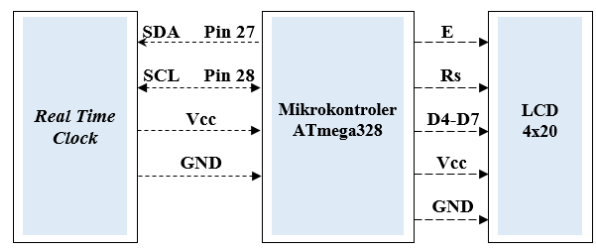

Gambar 15: Diagram blokpengujian rangkaian Real Time Clock

Hasil pengujian rangkaian Real Time Clock menggunakan mikrokontroler ATmega328 dengan tampilan LCD ditunjukkan pada Gambar 16.

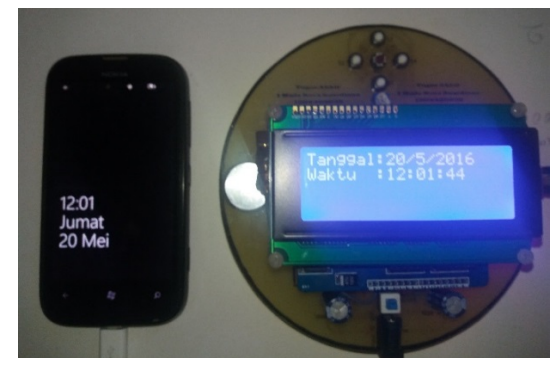

Gambar 16: Hasil pengujian rangkaian Real Time Clock

Pengujian rangkaian Real Time Clockdilakukan dengan membandingkan tampilan jam pada LCD dengan tampilan jam pada sebuah ponsel. Pada Gambar 16 pengujian pertama dilakukan pada 20 Mei 2016. Jika dibandingkan, tampilan pada LCD rangkaian Real Time Clockdengan tampilan pada ponsel, hasilnya sudah sesuai. Tingkat akurasi rangkaian RTC dengan waktu yang sebenarnya mencapai $100 \%$. Hal tersebut dibuktikan dengan hasil pengujian lainnya yang terkait dengan rangkaian RTC yang dilakukan pada 2 Juni 2016 yaitu pengujian terhadap respon dari modul IComSat V1.1-SIM900 Shield. Informasi waktu yang dihasilkan rangkaian RTCakan dikirimkan bersamaan dengan informasi jumlah konsumsi air pelanggan PDAM. Jika dibandingkan,Informasi waktu pada isi SMS yang diterima sudah sesuai dengan dengan informasi waktu pada saat ponsel mengirim SMS.

\section{F. Pengujian Keseluruhan Sistem}

Pengujian bertujuan untuk mengetahui kombinasi dari akurasi pembacaan water flow sensor YF-S201, hasil konversi dalam satuan pembayaran dengan variasi aliran debit air, akurasi informasi waktu dan tanggal serta respon dari modul IComSat V1.1-SIM900 Shield ke ponsel pelanggan maupun petugas PDAM.

Pengujian pembacaanwater flow sensor YF-S201 dilakuakan selama 50 kali dengan asumsi 1 Liter hasil pembacaan pada alat $=1 \mathrm{~m}^{3}$ pada di lapangan. Hal tersebut dilakukan hanya saat pengujian untuk efisiensi waktu dan menguji hasil konversi dalam Rupiah. Hasil pengujian pembacaan sensor dan hasil konversi dalam satuan pembayarandengan variasi debit air 0,075 Liter/detik, dan 0,025 Liter/detik ditunjukkan pada Tabel 3.

I Made Nova Suardiana :Rancang Bangun Sistem Pembacaan...
TABEL III

HASIL PENGUJIAN KESELURUHAN SISTEM

\begin{tabular}{|c|c|c|c|c|c|c|}
\hline \multirow[t]{2}{*}{ No } & \multicolumn{2}{|c|}{$\begin{array}{c}\text { Debit Air } \\
\text { 0,075 Liter/detik }\end{array}$} & \multicolumn{2}{|c|}{$\begin{array}{c}\text { Debit Air } \\
\text { 0,025 Liter/detik }\end{array}$} & \multirow{2}{*}{$\begin{array}{l}\text { Vol. } \\
\text { Air } \\
\left(\mathrm{m}^{3}\right)\end{array}$} & \multirow{2}{*}{$\begin{array}{l}\text { Hasil } \\
\text { Konversi } \\
\text { Sensor } \\
(\mathrm{Rp})\end{array}$} \\
\hline & $\begin{array}{l}\text { Jumlah } \\
\text { Putaran } \\
\text { Sensor }\end{array}$ & $\begin{array}{c}\text { Hasil } \\
\text { Konversi } \\
\left(\mathrm{m}^{3}\right)\end{array}$ & $\begin{array}{c}\text { Jumlah } \\
\text { Putaran } \\
\text { Sensor }\end{array}$ & $\begin{array}{c}\text { Hasil } \\
\text { Konversi } \\
\left(\mathrm{m}^{3}\right)\end{array}$ & & \\
\hline 1. & 446 & 0,99 & 430 & 0,96 & 1 & Rp. 27.000 \\
\hline 2. & 896 & 1,99 & 885 & 1,97 & 2 & Rp. 27.000 \\
\hline 3. & 1389 & 3,09 & 1340 & 2,98 & 3 & Rp. 27.000 \\
\hline 4. & 1812 & 4,03 & 1787 & 3,97 & 4 & Rp. 27.000 \\
\hline 5. & 2229 & 4,95 & 2244 & 4,99 & 5 & Rp. 27.000 \\
\hline 6. & 2719 & 6,04 & 2692 & 5,98 & 6 & Rp. 27.000 \\
\hline 7. & 3119 & 7,02 & 3148 & 7,00 & 7 & Rp. 27.000 \\
\hline 8. & 3590 & 7,98 & 3595 & 7,99 & 8 & Rp. 27.000 \\
\hline 9. & 4049 & 9,00 & 4048 & 9,00 & 9 & Rp. $\quad 27.000$ \\
\hline 10. & 4498 & 10,00 & 4491 & 9,98 & 10 & Rp. 27.000 \\
\hline 11. & 4954 & 11,01 & 4951 & 11,00 & 11 & Rp. 31.250 \\
\hline 12. & 5404 & 12,01 & 5392 & 11,98 & 12 & Rp. 35.500 \\
\hline 13. & 5858 & 13,02 & 5835 & 12,97 & 13 & Rp. 39.750 \\
\hline 14. & 6317 & 14,04 & 6297 & 13,99 & 14 & Rp. 44.000 \\
\hline 15. & 6767 & 14,99 & 6739 & 14,98 & 15 & Rp. 48.250 \\
\hline 16. & 7196 & 15,99 & 7201 & 16,02 & 16 & Rp. 52.500 \\
\hline 17. & 7667 & 17,04 & 7640 & 16,98 & 17 & Rp. 56.750 \\
\hline 18. & 8101 & 18,00 & 7658 & 17,02 & 18 & Rp. 61.000 \\
\hline 19. & 8538 & 18,97 & 8551 & 19,00 & 19 & Rp. 65.250 \\
\hline 20. & 9018 & 20,04 & 8987 & 19,97 & 20 & Rp. 69.500 \\
\hline 21. & 9438 & 20,97 & 9453 & 21,01 & 21 & Rp. 74.600 \\
\hline 22. & 9884 & 21,96 & 9903 & 22,01 & 22 & Rp. 79.700 \\
\hline 23. & 10370 & 23,04 & 10373 & 23,05 & 23 & Rp. 84.800 \\
\hline 24. & 10739 & 23,96 & 10805 & 24,01 & 24 & Rp. 89.900 \\
\hline 25. & 11234 & 24,96 & 11256 & 25,01 & 25 & Rp. 95.500 \\
\hline 26. & 11690 & 25,98 & 11707 & 26,02 & 26 & Rp. 100.100 \\
\hline 27. & 12148 & 27,00 & 12159 & 27,02 & 27 & Rp. 105.200 \\
\hline 28. & 12607 & 28,02 & 12591 & 27,98 & 28 & Rp. 110.300 \\
\hline 29. & 13067 & 29,04 & 13062 & 29,03 & 29 & Rp. 115.400 \\
\hline 30. & 13486 & 97 & 13495 & 29,99 & 30 & Rp. 120.500 \\
\hline 31. & 13950 & 31,00 & 13948 & 31,00 & 31 & Rp. 126.450 \\
\hline 32. & 14415 & 32,03 & 14401 & 32,00 & 32 & Rp. 132.400 \\
\hline 33. & 14839 & 32,98 & 14855 & 33,01 & 33 & Rp. 138.350 \\
\hline 34. & 15306 & 34,01 & 15309 & 34,02 & 34 & Rp. 144.300 \\
\hline 35 . & 15731 & 34,96 & 15743 & 34,98 & 35 & Rp. 150.250 \\
\hline 36. & 16200 & 36,00 & 16198 & 36,00 & 36 & Rp. 156.200 \\
\hline 37. & 16670 & 37,04 & 16652 & 37,00 & 37 & Rp. 162.150 \\
\hline 38. & 17099 & 38,00 & 17104 & 38,01 & 38 & Rp. 168.100 \\
\hline 39. & 17573 & 39,05 & 17558 & 39,02 & 39 & Rp. 174.050 \\
\hline 40 & 18004 & 40,01 & 17992 & 39,98 & 40 & Rp. 180.000 \\
\hline 41 & 18436 & 40,97 & 18446 & 40,99 & 41 & Rp. 185.950 \\
\hline 42 & 18912 & 42,03 & 18899 & 42,00 & 42 & Rp. 191.900 \\
\hline 43. & 19345 & 42,99 & 19353 & 43,01 & 43 & Rp. 197.850 \\
\hline 44 & 19823 & 44,05 & 19808 & 44,02 & 44 & Rp. 203.800 \\
\hline 45 . & 20256 & 45,01 & 20262 & 45,03 & 45 & Rp. 209.750 \\
\hline 46 & 20692 & 45,98 & 20698 & 46,00 & 46 & Rp. 215.700 \\
\hline 47. & 21127 & 46,95 & 21153 & 47,01 & 47 & Rp. 221.650 \\
\hline 48 & 21606 & 48,01 & 21608 & 48,02 & 48 & Rp. 227.600 \\
\hline 49. & 22043 & 48,98 & 22042 & 48,98 & 49 & Rp. 233.550 \\
\hline 50 & 22481 & 49,96 & 22497 & 49,99 & 50 & Rp. 239.500 \\
\hline
\end{tabular}

p-ISSN:1693 - 2951; e-ISSN: 2503-2372 
Saat pengujian pembacaan water flow sensor YFS201berlangsung, pengujian terhadap respon dari modul IComSat V1.1-SIM900 Shieldtetap dapat dilakukan. Saat total pemakaian pelanggan PDAM mencapai $10 \mathrm{~m}^{3}$, modul IComSat V1.1-SIM900 Shieldakan mengirimkan peringatan kepada pelanggan PDAM.Ppengujian lainnya dapatdilakukan dengan mengirimkan perintah kepada sistem. Untuk pelanggan PDAM dapat mengirimkan perintah "CEK" sedangkan untuk petugas PDAM dapat mengirimkan perintah "PDAM". Tampilan SMS pada ponsel pelanggan PDAM saat menerima peringatan pemakaian dan saat pelanggan PDAM mengirim SMS "CEK" untuk mengetahui informasi jumlah pemakaian air pelanggan PDAM ditunjukkan pada Gambar 17.

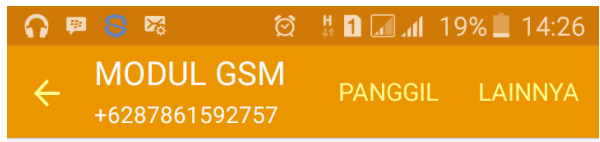

\section{Kamis, 02 Juni 2016}

Pelanggan yang terhormat, jumlah pemakaian air saat ini sudah memasuki standar pemakaian $=10$ meter kubik. SMS 14:25 1

Gambar 17: SMS yang dikirim dan diterima oleh pelanggan PDAM

Tampilan LCD saat mengirimkan SMS informasi jumlah pemakaian air kepada pelanggan PDAM ditunjukkan pada Gambar 18

SwS telah terkirim

$\mathrm{ke}$ Pel angean

$14: 25: 39 \quad 2-6-2016$

14.61 m $\mathrm{RF} \cdot 4825 \mathrm{~g}$

Gambar 18: Tampilan LCD saat mengirim SMS kepada pelanggan PDAM

Pada LCD terdapat informasi tanggal dan waktu pengiriman serta informasi jumlah pemakaian air dalam satuan $\mathrm{m}^{3}$ dan dalam satuan Rupiah. Selanjutnya dapat dibandingkan dengan informasi yang didapat dari SMS balasan pada ponsel pelanggan PDAM. Tampilan SMS balasan yang diterima pelanggan PDAM dari sistem ditunjukkan pada Gambar 19.

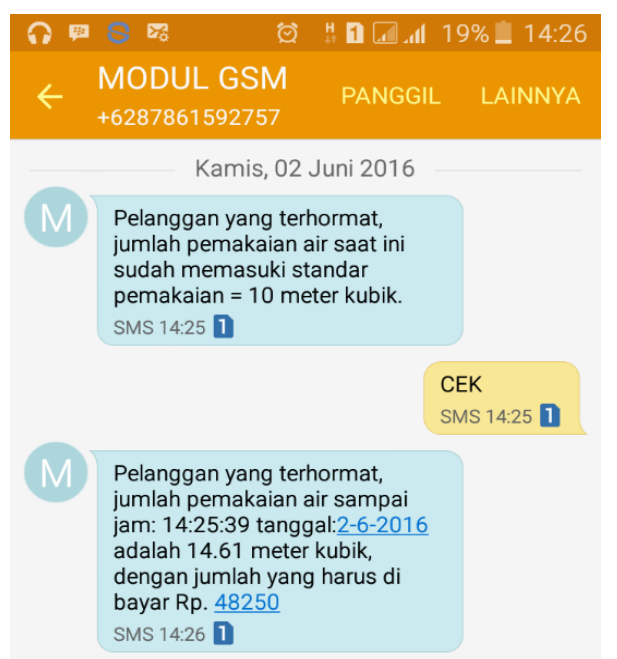

Gambar 19: SMS balasan yang diterima pelanggan PDAM

SMS balasan berisikan informasi waktu dan tanggal serta jumlah pemakaian air dalam satuan $\mathrm{m}^{3}$ dan dalam satuan Rupiah. Jika dibandingkan, tampilan informasi pada LCD dengan tampilan pada ponsel pelanggan PDAM sudah sesuai. Baik pada LCD maupun ponsel pelanggan PDAM jumlah pemakaian air adalah $14,61 \mathrm{~m}^{3}$ dengan jumlah yang harus dibayar sebesar Rp. 48.250.

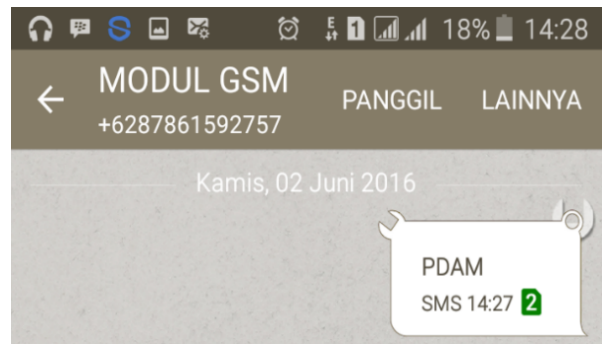

Gambar 20: SMS yang dikirim oleh petugas PDAM

Gambar 20 menunjukkan tampilan SMS pada ponsel petugas PDAM saat mengirim SMS "PDAM" untuk mengetahui informasi jumlah pemakaian air pelanggan PDAM.

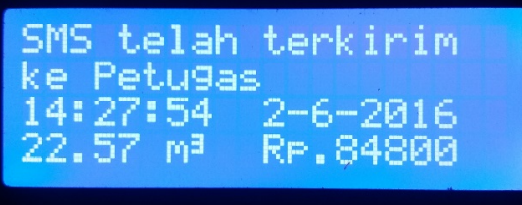

Gambar 21: Tampilan LCD saat mengirim SMS kepada petugas PDAM

ISSN 1693-2951 I Made Nova Suardiana : Rancang Bangun Sistem Pembacaan... 
Gambar 21 menunjukkan tampilan LCD saat mengirimkan SMS informasi jumlah pemakaian air kepada petugas PDAM. Selanjutnya dapat dibandingkan dengan informasi yang didapat dari SMS balasan pada ponsel petugas PDAM. Gambar 22 menunjukkan tampilan SMS balasan yang diterima petugas PDAM dari sistem.

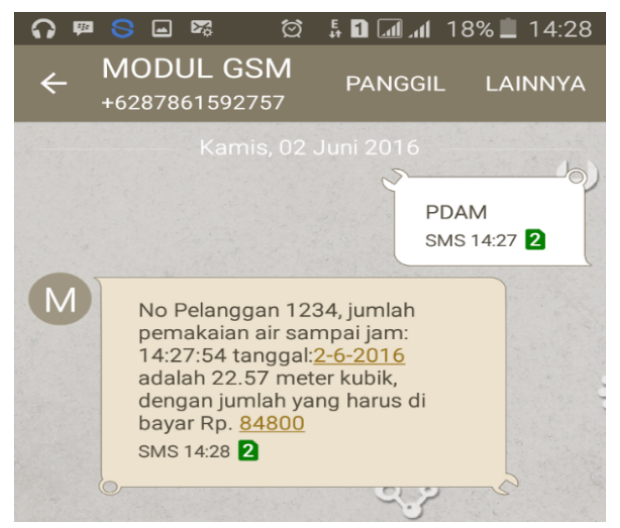

Gambar 22: SMS balasan yang diterima petugas PDAM

SMS balasan berisikan informasi waktu dan tanggal serta jumlah pemakaian air dalam satuan $\mathrm{m}^{3}$ dan dalam satuan dengan tampilan pada ponsel petugas PDAM sudah sesuai. Baik pada LCD maupun ponsel petugas PDAM jumlah pemakaian air adalah $22,57 \mathrm{~m}^{3}$ dengan jumlah yang harus dibayar sebesar Rp. 84.800.

Dari hasil pengujian terhadap respon dari modul IComSat V1.1-SIM900 Shieldyang tercatat, dilakukan sebanyak 3 kali yaitu: peringatan pemakaian $10 \mathrm{~m}^{3}$, saat menerima perintah "CEK" dari pelanggan PDAM dan saat menerima perintah "PDAM" dari petugas PDAM. Dari hasil pengujian tersebut tidak terjadi kegagalan pengiriman SMS. Namun dari pengujian-pengujian sebelumnya, kegagalan pengiriman SMS hanya terjadi saat pulsa pada alat tidak mencukupi. Penundaan pengiriman SMS terjadi saat jaringan tidak mendukung. SMStetap akanditerima oleh alat dan alat akan mengirimkan SMS balasan pada kondisi pulsa dan jaringan yang sudah mendukung.

\section{G. Pengujian Dan Pembahasan Konsumsi Daya Listrik}

Pengujian konsumsi daya listrik bertujuan untuk mengetahui besarnya konsumsi daya dari alat yang direalisasikan.Pengujian konsumsi daya listrik menggunakan alat ukur digital multy-functiom meterdengan sumber tegangan adaptor 9,32 VDC. Pengukuran dilakukan pada interval waktu 30 menit, 70 menit dan 145 menit. Hasil pengujian konsumsi daya pada ditunjukkan pada Tabel 4.

\section{TABEL III}

HASIL PENGUJIAN KONSUMSI DAYA LISTRIK

\begin{tabular}{|l|c|c|c|c|}
\hline \multirow{2}{*}{ No. } & Jenis & \multicolumn{3}{|c|}{ Waktu Pengujian } \\
\cline { 3 - 5 } & Pengukuran & 30 menit & 70 menit & 145 menit \\
\hline 1. & Tegangan & $9,32 \mathrm{VDC}$ & $9,32 \mathrm{VDC}$ & $9,32 \mathrm{VDC}$ \\
\hline 2. & Arus & $0,09 \mathrm{~A}$ & $0,09 \mathrm{~A}$ & $0,09 \mathrm{~A}$ \\
\hline
\end{tabular}

I Made Nova Suardiana :Rancang Bangun Sistem Pembacaan...

\begin{tabular}{|l|c|c|c|c|}
\hline 3. & Daya & $0,8 \mathrm{~W}$ & $0,8 \mathrm{~W}$ & $0,8 \mathrm{~W}$ \\
\hline 4. & Energi & $0 \mathrm{Wh}$ & $1 \mathrm{Wh}$ & $2 \mathrm{Wh}$ \\
\hline
\end{tabular}

Dari hasil pengukuran diperoleh rata-rata dalam 1 jam alat menghabiskan energi sebesar $0,8 \mathrm{Wh}$. Jika dihitung dalam satu hari jumlah konsumsi daya sebesar 19,2 Wh, dan jika diakumulasikan dalam satu bulan, jumlah konsumsi daya sebesar $0,58 \mathrm{kWh}$ sehingga total pembayaran dalam waktu satu bulan untuk daya yang terpasang $900 \mathrm{VA}$ dengan harga per kWh Rp. 605 adalah sebesar Rp. 348,5.

\section{SimpUlan}

Rancang bangun sistem pembacaan jumlah konsumsi air pelanggan PDAM berbasis mikrokontroler ATmega328 dilengkapi SMS dapat diimplementasikan dengan baik menggunakan water flow sensor YF-S201 dan telah dapat mengukur jumlah konsumsi air pelanggan PDAM dengan rata-rata penyimpangan sebesar 0,39\%. Pelanggan PDAM akanmendapatkan kemudahan akses mengenai data jumlah konsumsi air dengan tambahan tampilan dalam satuan pembayaran. Pengujian menunjukkan hasil konversi pembayaran sudah sesuai dengan model pembayaran PDAM di Kabupaten Gianyar dengan Golongan Non Niaga (NA) untuk Rumah Tangga (NA.1).Pengiriman data dipilih menggunakanmedia SMS dengan pertimbangan lebih ekonomis dibandingkan media internet karena sistem akan selalu bekerja dan memberikan akses kapanpun kepada pelanggan dan petugas PDAM. Sistem bekerja dengan konsumsi daya listrik sebesar 0.8 Watt.

\section{REFERENSI}

[1] Sean Setya Henura, Triyogatama Widodo Wahyu. 2015. Rancang Bangun Sistem Jaringan Nirkabel Untuk Pemantauan Konsumsi Air Pelanggan PDAM" Universitas Gajah Mada [online]. Available:http://journal.ugm.ac.id/ijeis/article/view/7639/5922

[2] (2012). Datasheet Water Flow Sensor G $1 / 2$ inch [online]. Available: https://partelektrik.wordpress.com/2012/09/27/jual-water-flow-sensorsensor-filling/water-flow/

[3] (2010). Simulasi Arduino menggunakan Proteus VSM. [online] Available:http://agfi.staff.ugm.ac.id/blog/index.php/2010/09/simulasiarduino-menggunakan-proteus-vsm/.

[4] Paramarta P. M. N 2016. "Rancang Bangun Pendeteksi Kebocoran LPG

Menggunakan Sensor TGS2610 Dilengkapi SMS Berbasis Mikrokontroler ATmega328". Denpasar: Universitas Udayana; 2016.

[5] "IComsat v1.1-SIM900 GSM/GPRS Shield data sheet," ITead Studio.

[6] "DS1307 data sheet," Dallas Semiconductor.

[7] (2010). Mudah Menguasai Pemrograman Mikrokontroler Atmel AVR Menggunakan Bascom-AVR. [online].Available:http://agfi.staff.ugm.ac.id/blog/index.php/2011/02/e book_mikrokontroler_bascom_avr/.

[8] (2009) PDAM Kab. Gianyar. Pengumuman Penyesuaian Tarif Air Minum PDAM Kabupaten Gianyar. 
\{ Sengaja di kosongkan\}

ISSN 1693-2951 I Made Nova Suardiana : Rancang Bangun Sistem Pembacaan... 